The microphones used were of the moving coil type and, with one exception, they were carefully hidden. The engineer responsible for the arrangements sat in the crypt operating the controls for the various microphones required for the different portions of the ceremony, ranging from the running commentary outside the Abbey to the actual service at the altar steps. The various circuits were faded in and out so smoothly that the impression conveyed to the listener was that only one microphone was being used, and that it was being transferred from point to point as required. Four special telephone circuits were established between the control room and Broadcasting House, and from the latter centre the programme was distributed through all the home and Empire broadcasting stations. The developments of broadcasting and communications technique during recent years were utilised in the above manner to make this wedding ceremony an outstanding event in history ; for, as the Archbishop of Canterbury remarked in his address, never before has a marriage been attended by so vast a company of witnesses.

\section{An Experimental Railway Journey at High Speed}

ON November 30, the London and North Eastern Railway made an experimental run with a train from London to Leeds and back, to demonstrate what the possibilities were with steam as compared with oil. For the outward journey, the train was made up of locomotive No. 4472, a 'Flying Scotsman' engine, with a dynamometer car, a first-class corridor coach, a dining car and a brake van, while for the homeward journey two other corridor coaches were added, increasing the weight behind the engine from 145 tons to 205 tons. The train left King's Cross at 9.8 a.m. and arrived at Leeds at 11.39 a.m., the distance being 185.7 miles and the average speed being 73.4 miles per hour. The return journey was begun at 2.0 p.m. and ended at 4.37 p.m. During the return run, between Grantham and Peterborough, a maximum speed of 100 miles an hour was recorded, while during the climb from Tallington to Corby the speed was never less than 80 miles per hour. The experimental run was intended as a test of the steam locomotive burning coal on a service similar to that now run in foreign countries by trains with Dieselengined locomotives. The most notable of these trains at the present moment is the Flying Hamburger, which covers the distance between Berlin and Hamburg daily at an average speed of 77 miles an hour. The line over which the Flying Hamburger travels is level and without curves, while the line between King's Cross and Leeds has gradients up to 1 in 100 , and several speed restrictions. Such a passage as that made on November 30 , of course, could not be made without a certain amount of dislocation to other traffic and it was expensive ; but it showed that the potentialities of the steam locomotive for high-speed work have not been exhausted. It is noteworthy that the engine used is stated to have run some $\mathbf{4 4 , 0 0 0}$ miles since its last overhaul.

\section{Launching of Long-Range Aeroplanes}

Investigation into the possibilities of a new method of overcoming the difficulties of taking off with fuel sufficient for a long flight together with a reasonable amount of useful load, will shortly be carried out under the auspices of the Air Ministry and Imperial Airways by the use of a 'composite seaplane' now being built by Messrs. Short Brothers of Rochester. The machine is a flying boat, with sufficient initial climb to be able to take off the water easily with an exceptionally heavy load. The major portion of this load is a high-speed float seaplane, the design characteristics of which are those required for economical long-distance flight. It is carried practically on the wings of the flying boat, from which it can be released when sufficient speed and height are attained. The power of both of the machines is used for taking off. For this experiment a small single-engined seaplane will be used, which will probably not be seaworthy enough to weather rough water on the open seas if compelled to alight. It is, however, capable of flying to the Azores under normal conditions, and in the rarely favourable case of a continuous following wind, even to fly the whole of the direct crossing to America. The problem of securing exceptional range has hitherto been dealt with by refuelling in the air immediately after start. ing. The operating aircraft takes off with a small fuel load and is then filled from a 'tanker' machine, by means of a trailing hose picked up and connected while in flight. This system has been developed successfully by the R.A.F., but has never been used extensively for either military or commercial purposes.

\section{Airship Developments in the United States}

According to Science Service, of Washington, D.C., one of the older U.S. naval Zeppelin airships, the Los Angeles, has been reconditioned and made fully airworthy for a series of experiments upon mooring. It will be maintained in ordinary flying condition and moored out of doors, in the usual way, for at least a complete year. Experience thus gained will help to settle a number of questions upon which it is impossible to theorise. These include estimation of the velocity and extent of winds and gusts, the behaviour of the airship when under the effects of these and other meteorological conditions, the best handling of the ship to counteract the adverse effects of such, taking on supplies, fuel, etc., development of the ideal mooring system, and methods of docking into a hangar. Such information should be obtained with greater expedition and safety, using a trained experimental staff in this way, than endeavouring to gain similar experience during the normal using of the airship in service.

\section{Development of Cargo Vessels}

The seventh Thomas Lowe Gray lecture to the Institution of Mechanical Engineers was delivered on November 30 by Mr. L. St. L. Pendred, who took for the title of his lecture "A Survey of Ships and Engines". Although, in the first part of his lecture, 
Mr. Pendred recalled some of the historic vessels and a few of the notable inventions connected with marine propulsion in the early days of steam navigation, he avoided the well-trodden path which leads to the epoch-making ships connected with ocean travel or with fighting fleets, and turned aside to consider the development of ships designed especially for cargo carrying. These he said are "the lesser vessels which do the come-day go-day work of the world; the tramps and freighters slogging their patient way across the Bay, facing typhoons in the China Sea, picking their courses 'twixt Scylla and Charybdis, nosing themselves into little ports looking for cargoes; never certain where next their lawful occasions may take them". By means of curves of tonnage, horse-power, speed, steam pressures and the like, he endeavoured to show how, in these as in all ships, economy has been attained. In 1887 a typical tramp had a displacement of 4,840 tons ; in 1896, 7,075 tons; in 1911, 10,000 tons and in $1928,12,380$ tons ; and during this time the coal consumption per knot per ton dead weight carrying capacity had fallen 40 per cent. To those who would call a halt to invention he said, "not the wills of all the anti-mechanization people in the whole world will check for a fraction of a second the wheel that began to spin a hundred and forty years ago when James Watt produced the rotative steam engine". Further economy in cargo ships must be and will be sought.

\section{The Waitaki Hydro-electric Installation, New Zealand}

The opening on October 26 by Lord Bledisloe, Governor-General of the Dominion of New Zealand, of the hydro-electric power station near Kurow, on the Waitaki River in the South Island, was the occasion of an imposing ceremony attended by the Prime Minister (the Right Hon. G. W. Forbes) and other ministers and public men. It was a noteworthy event in the annals of the country, being the inauguration of the largest installation of water-power so far developed there. The following brief details of the undertaking are extracted from the Wellington Evening Post. The total length of the impounding dam is $1,800 \mathrm{ft}$., with a spillway $1,200 \mathrm{ft}$. long. The structure, which contains half a million tons of concrete, has a maximum height of $120 \mathrm{ft}$. and a base width of $145 \mathrm{ft}$. The power house, $350 \mathrm{ft}$. long, $150 \mathrm{ft}$. wide and $130 \mathrm{ft}$. high, is an integral part of the dam and provides for the reception of five turbo-generators, each of 23,000 horse-power, of which only two, as yet, have been installed. Lord Bledisloe in his address said that electric supply is available to no less than 94 per cent of the total population (a percentage probably not exceeded in any other country in the world) with an average consumption per capita of about 500 units per annum. The total capital invested in electrical supply undertakings in New Zealand is $£ 32,000,000$, of which $£ 28,000,000$ has been expended during the last eleven years. During the same period, Government expenditure has amounted to $£ 10,500,000$. The average cost of eurrent for ordinary domestie purposes is $1 \cdot 31 d$. per unit as compared with $1 \cdot 30 d$. in Great Britain and $1 \cdot 39 d$. in the United States. Lord Bledisloe urged a fuller recognition of the complementary possibilities of user on the part of urban and rural consumers, and the extent to which one could assist the other.

\section{Mangarevan Expedition of the Bernice P. Bishop Museum}

ON October 28, Bernice P. Bishop Museum welcomed the natural history party of the Mangarevan Expedition returning to Honolulu aboard the specially designed sampan Islander from six months' field work in south-eastern Polynesia. The Mangarevan Expedition was organised for the explora. tion of little-known islands and atolls in extreme south-eastern Polynesia. Of the thirty-one islands and many atolls and reefs on which the party landed, particular attention was given to Anaa, Napuka, Tatakoto, Hao, Mangareva, Timoe, Pitcairn, Henderson, Oeno, Rapa, Raivavae, Rurutu and Rimatara. Surveys supplementing those made by Bishop Museum in previous years were conducted at Tubuai, Tahiti, Raiatea, Huahine and Borabora. To gain access to atolls and cliff-bound volcanic islands, a ship of high power and shallow draught was designed, and to permit the party to divide its forces for particular kinds of work, a transfer ship and power launches were provided. The expedition was made possible by generous grants from the Rockefeller Foundation and from institutions and individuals in Hawaii. Regarding the expedition, Prof. Herbert E. Gregory, director of Bernice P. Bishop Museum, remarks: "Under the experienced leadership of Dr. D. Montague Cooke, ably supported by Captain William Anderson of the Islander, the program of the expedition was carried out with marked success. The collections, which include some 15,000 sheets of plants, 40,000 insects, 160,000 land shells, and representative series of other animals, is sufficient to give a fairly complete picture of the land fauna and flora of the southeastern Pacific, and to indicate the relation of the oceanic islands to South America. The expedition practically completed the general survey of the ethnology and natural history of Polynesia which has been the chief interest of the Museum since 1920."

\section{Third International Locust Conference}

IT is not unusual for proceedings of international scientific congresses to be published some months, or even years later, but this cannot be said with regard to the Third International Locust Conference held in London in September (see NATure, 134, 484, Sept. 29, 1934). The volume of its proceedings was issued by H.M. Stationery Office two months after the Conference. It is a very compact publication which contains in its 184 pages a mass of first-hand and thoroughly up-to-date information on the locust problem. The official part of the proceedings occupies only a relatively small portion of the volume, while the bulk of it consists of papers presented by various experts. The papers deal with all sides of the locust problem in a very brief and concise manner, discussing the most important points to be investigated 